\title{
On-farm characterization and evaluation of dairy cattle crossbreeds in Côte d'Ivoire
}

\author{
Edouard K. N'Goran ${ }^{1 \dagger}$, Valentine C. Yapi Gnaore ${ }^{2}$ and Agathe T. Fantodji ${ }^{1}$ \\ ${ }^{1}$ UFR/SN, Université d'Abobo Adjamé, Abidjan, Côte d'Ivoire; ${ }^{2}$ Centre National de Recherche Agronomique (CNRA), Abidjan, Côte d'Ivoire
}

\section{Background}

For national milk production improvement, the anarchical dairy crossbreeding involving local and European breeds have been performed in the Côte d'Ivoire. In this way the Ivorian dairy crossbreed genetic identification and their production trend knowledge constitute a challenge in dairy cattle breeding development strategy.

\section{Material and methods}

A characterization and evaluation study was conducted on 142 cows from six smallholder dairy farms in the peri-urban area of Abidjan. The farms are held by rural farmers, and are advised by the Ministry of Animal production through dairy cattle breeding development projects. The animals have been described using descriptors defined by the FAO (1986). Linear body measurements and the qualitative characters were determined using a metric ribbon and visual appreciation criteria respectively. Ages at first calving (AFC), average milk yield per day (AMD), lactation length (LL) and calving interval $(\mathrm{CI})$ were evaluated with the farmers help. Statistical analysis for the various production traits and body measurements were performed by XLSTAT 7.5.3 (Saporta, 1990).

\section{Results}

Three major dairy crossbreeds $F_{1} N^{\prime}$ Damance $\left(F_{1} N D c e\right)$, $F_{1}$ Montbéliarde $\left(F_{1} M t b\right)$ and $3 / 4$ Montbéliarde $(3 / 4 \mathrm{Mtb})$ were found under a semiintensive system. They were well adapted to local climatic and environmental conditions. These cows distinguished themselves into two groups according to their body length and heart girth. When body length coupled to heart girth were considered, the $F_{1} N D c e$ and $F_{1} M t b$ animals were bigger than the $3 / 4 \mathrm{Mtb}$ animals (Table 1).

Regarding the milk production traits, the $3 / 4 \mathrm{Mtb}$ genetic type confirmed the best production trend than the $F_{1} N$ Nce and the $F_{1} M$ tb (table 2).

Average milk yield varied statistically within the genetic types. It varied from 1.5 to 7 liter, from 2 to 6.5 liter and from 2 to 9.3 liter for the $F_{1} N D c e$, the $F_{1} M t b$ and the $3 / 4 \mathrm{Mtb}$, respectively. The coefficient of variations were $33.1 \%, 30.6 \%$ and $30.1 \%$ for the $F_{1} N D c e$, the $F_{1} M t b$ and the $3 / 4 \mathrm{Mtb}$, respectively. These results show that there is a diversity to cow inside each genetic type. However milk average range according to the season (table 2) shows that the season seems to have a significant effect on the cows' lactation.

Table 1 Overview of least squares means comparison for body measurements ( \pm S.E)

\begin{tabular}{lllllllll}
\hline \hline & LgA $(\mathrm{cm})$ & HTG $(\mathrm{cm})$ & PTH $(\mathrm{cm})$ & Pds $(\mathrm{kg})$ & LgT $(\mathrm{cm})$ & FAS $(\mathrm{cm}$ & LgQ $(\mathrm{cm})$ & ORL $(\mathrm{cm})$ \\
\hline F NDce $_{1}$ & $184.8^{\mathrm{a}} \pm 9.5$ & $125.1 \pm 5.9$ & $164.6^{\mathrm{ab}} \pm 10.1$ & $362.5^{\mathrm{ab}} \pm 66.4$ & $50.2^{\mathrm{a}} \pm 1.8$ & $21.6 \pm 1.6$ & $100.0^{\mathrm{a}} \pm 6.2$ & $20.2^{\mathrm{a}} \pm 2.8$ \\
F $_{1}$ Mtb & $181.6^{\mathrm{a}} \pm 8.7$ & $124.3 \pm 4.9$ & $167.0^{\mathrm{a}} \pm 8.8$ & $375.1^{\mathrm{a}} \pm 66.5$ & $49.0^{\mathrm{b}} \pm 1.9$ & $21.0 \pm 1.2$ & $97.1^{\mathrm{ab}} \pm 5.3$ & $18.8^{\mathrm{b}} \pm 2.2^{\mathrm{b}}$ \\
3/4Mtb & $175.1^{\mathrm{b}} \pm 14.1$ & $123.8 \pm 5.9$ & $160.8^{\mathrm{b}} \pm 10.4$ & $340.1^{\mathrm{b}} \pm 62.5$ & $48.5^{\mathrm{b}} \pm 3.2$ & $217 \pm 1.7$ & $96.3^{\mathrm{b}} \pm 8.1$ & $20.21^{\mathrm{a}} \pm 2.3^{2}$ \\
\hline \hline
\end{tabular}

$\mathrm{LgA}=$ Body length, HTG = height wither, PTH = heart girth, Pds = body weight, $\mathrm{LgT}=$ head length, $\mathrm{ORL}=$ ear length and $\mathrm{LgQ}=\mathrm{tail}$ length.

NB: within row the least squares means with the same superscript are not significantly $(P<0.05)$ different.

Table 2 Comparison of least squares means $( \pm$ S.E) for cow dairy performances

\begin{tabular}{|c|c|c|c|c|c|c|}
\hline & \multirow[b]{2}{*}{ AFC (month) } & \multirow[b]{2}{*}{ MY (litre) } & \multirow[b]{2}{*}{ LL (days) } & \multirow[b]{2}{*}{$\mathrm{Cl}$ (days) } & \multicolumn{2}{|c|}{ Milk average yield range per season } \\
\hline & & & & & 2004-2005 & 2005-2006 \\
\hline $\mathrm{F}_{1} \mathrm{NDce}$ & $35.8^{b} \pm 6.16$ & $4.4^{b} \pm 1.45$ & $249^{b} \pm 33.4$ & $456^{a} \pm 9.54$ & $1,5-6$ & $2-7$ \\
\hline $\mathrm{F}_{1} \mathrm{Mtb}$ & $40.4^{a} \pm 7.05$ & $4.3^{b} \pm 1.31$ & $246^{b} \pm 52.61$ & $434^{b} \pm 49.20$ & $2-6.2$ & $2.5-6.5$ \\
\hline 3/4Mtb & $34.8^{b} \pm 8.07$ & $5.25^{a} \pm 1.58$ & $255^{a b} \pm 50.41$ & $445^{a b} \pm 14.10$ & $2-7.6$ & $3-9.3$ \\
\hline
\end{tabular}

$\mathrm{AFC}=$ age at first calving, $\mathrm{MY}=$ average milk yield per day, $\mathrm{LL}=$ lactation length, $\mathrm{Cl}=$ calving interval. NB: within row least squares means with the same superscript are not significantly $(P<0.05)$ different.

\footnotetext{
†E-mail: ngoren_a@yahoo.fr
} 


\title{
Conclusion
}

The $F_{1}$ NDce and $F_{1} M t b$ seem similar for their physical characteristics whereas they are bigger than the 3/4 Mtb animals. But compared with the both $F_{1} N D c e$ and $F_{1} M t b$, the $3 / 4$ Mtb cows performed the best milk production trends which would be related to exotic gene level increasing.

\section{References}

FAO 1986. Animal Genetic Resources Data Bank: Descriptors List for Cattle, Buffalo, Pigs, Sheep and Goats. FAO, Rome, Italy, pp. 150.

Saporta G 1990. Probabilité, analyse des données et statistique. Technip, Paris, pp. 403-423.

\section{Studies on the adaptability of Jersey $\times$ Sahiwal crossbred cattle to tropical conditions and their productive performance}

\author{
K. Sarjan $\operatorname{Rao}^{\dagger}$ \\ College of Veterinary Science, Sri Venkateswara Veterinary University, Proddatur, India
}

Crossbreeding plays a vital role in the improvement of productive and reproductive performance of native cattle in developing countries like India. The Jersey cattle breed is the breed of choice for crossbreeding as it suits well to the tropical climate of India. In order to bring about Genetic improvement of the crossbred cattle, there is a strong need to produce genetically superior bulls in required members for artificial insemination and natural services. The present work was therefore focused on the establishment of a bull mother farm of proven germplasm of Jersey $\times$ Sahiwal crossbred animals so as to supply young breeding bulls of proven germ plasma. Hence there is a need to test the productive performance and adaptability of crossbred animals to tropical conditions in order to establish the farm. The physiological data and results of biochemical analysis of blood samples of twenty-one Jersey $\times$ Sahiwal crossbred cows were noted regularly at weekly intervals. The milk production and peak yield were recorded and the milk samples were analysed for fat, protein and solids not fat (SNF).

The mean \pm SE values of temperature, pulse and respiration were recorded as $101.53 \pm 0.07,57.88 \pm 0.76$ and $23.13 \pm 0.58$ respectively. The mean \pm values of biochemical analysis of blood samples were $94.64 \pm 2.84,27.58 \pm 1.45,61.78 \pm 1.94,2.06 \pm 0.90$, $1.42 \pm 0.07,10.27 \pm 0.32,6.03 \pm 0.09,1.97 \pm 0.04,146.1 \pm 3.3$ and $4.81 \pm 0.11$ respectively for SGOT $\left(\mu L^{-1}\right), S^{2}$ SPT $\left(\mu L^{-1}\right)$, glucose $\left(\mathrm{mg} \mathrm{dL}^{-1}\right)$, urea $\left(\mathrm{mg} \mathrm{dL}^{-1}\right)$, creatinine $\left(\mathrm{mg} \mathrm{dL}^{-1}\right)$, calcium $\left(\mathrm{mg} \mathrm{dL}^{-1}\right)$, phosphorus $\left(\mathrm{mg} \mathrm{dL}^{-1}\right)$, magnesium $\left(\mathrm{mg} \mathrm{dL}^{-1}\right)$, sodium $\left(\mathrm{mg} \mathrm{dL}^{-1}\right)$, and potassium $\left(\mathrm{mg} \mathrm{dL}^{-1}\right)$ respectively which were all in the normal range for the crossbred cows. The mean total milk production (It) during the lactation and peak yield were $1345.9 \pm 0.25$ and $9.26 \pm 0.12$ respectively. The mean fat, protein and SNF percent were $4.90 \pm 0.10$, $3.67 \pm 0.03$ and $9.39 \pm 0.12$ respectively which were all in the normal range. The study suggests that the crossbreds were well adapted to the tropical climate and the bull mother farm can be established successfully so as to supply breeding bulls in surplus in the future to the farmers.

${ }^{\dagger}$ E-mail: kapasarjanreddy@yahoo.com

\section{Temperature-Humidity Index scenarios in the Mediterranean basin}

\author{
Maria Segnalini ${ }^{\dagger}$, Nicola Lacetera, Umberto Bernabucci and Alessandro Nardone \\ Dipartimento di Produzioni Animali, Università degli Studi della Tuscia, 01100, Viterbo, Italy
}

\section{Introduction}

In its 2007 assessment, the Intergovernmental Panel on Climate Change (IPCC) for the first time provided best estimates and likely ranges for global average warming under each of its emission scenarios. Based on plausible emission scenarios, the IPCC estimates that average surface temperatures could rise between $2^{\circ} \mathrm{C}$ and $6^{\circ} \mathrm{C}$ by the end of the 21 st century. Projected increases in temperature could cause more severe conditions of heat stress in farm animals and also a number of other effects (reduced growth and quality of grassland and crops, water availability, higher diffusion of vectorborn diseases, etc), which may indirectly impair animal health, welfare and performances (Lacetera et al., 2003). The Mediterranean basin has been

\footnotetext{
${ }^{\dagger}$ E-mail: m.segnalini@unitus.it
} 